\title{
PREVALENCE OF TOXOPLASMA GONDII AND POTENTIALLY ZOONOTIC HELMINTHS IN WILD BOARS (SUS SCROFA) HUNTED IN CENTRAL ITALY
}

\author{
Roberto Amerigo Papini, Sara Vannucci, Guido Rocchigiani, \\ Simona Nardoni, Francesca Mancianti \\ Department of Veterinary Sciences, Viale delle Piagge 2, 56124 Pisa, Italy
}

Received 1 October 2017; Received in revised form 18 January 2018; Accepted 22 January 2018

\begin{abstract}
Our aim was to evaluate the risk of human toxoplasmosis via meat consumption from wild boars by estimating the seroprevalence of Toxoplasma gondii in animals hunted in central Italy. Using a modified agglutination test, 213 sera from wild boars were examined for anti-Toxoplasma IgG antibodies. Diaphragm samples $(\mathrm{n}=65)$ from seropositive and seronegative animals were tested by nested-PCR to detect $T$. gondii DNA. Toxoplasma DNA from diaphragms was genotyped by PCR-RFLP using 12 genetic markers. Moreover, the aim of the study was also to identify helminth infections of wild boars in the selected area and to evaluate their hazard for humans. Examination of sera revealed a seroprevalence of $12.2 \%$. Only one $T$. gondii strain could be genotyped from a seropositive animal and PCR-RFLP revealed that it belonged to type II. Analysis of 50 samples of faeces and 32 small intestines revealed that $78 \%$ and $15.6 \%$ of the samples harboured parasites, respectively, with the occurrence of parasites potentially dangerous for humans. These latter included Ascaris suum, Macracanthorhynchus hirudinaceus, Trichuris suis, and Metastrongylus spp. A significant association was found between coprological positivity and male sex. These results indicate that $T$. gondii infection may be present in wild boar tissues and consumption of undercooked or raw wild boar meat may expose humans to risk of toxoplasmosis in the study area. Furthermore, the study highlights that wild boars are hosts of helminths of veterinary and medical importance transmissible to pigs and humans.
\end{abstract}

Key words: Toxoplasma gondii, prevalence, wild boars, zoonotic helminthiases, Italy

\section{INTRODUCTION}

The wild boar (Sus scrofa) is a large mammal species of greatest importance for hunting activity. This game animal is characterized by high prolificacy and extreme adaptability to a wide range of very different habitats (1). Such features have favoured the spread of wild boars in many parts of Europe, as well as in many Italian regions including Tuscany (2). In some areas, the wild boar population has been growing more and more over the years because of lack of predators, low hunting

Corresponding author: Dr. Roberto Amerigo Papini, PhD, EVPC Dipl. E-mail address: roberto.amerigo.papini@unipi.it

Present address: Department of Veterinary Sciences,

Viale delle Piagge 2, 56124 Pisa, Italy

Phone: 381214895310

Copyright: (C) 2018 Papini R.A. This is an open-access article published under the terms of the Creative Commons Attribution License which permits unrestricted use, distribution, and reproduction in any medium, provided the original author and source are credited.

Competing Interests: The authors have declared that no competing interests exist.

Available Online First: 15 February 2018

Published on: 15 March 2018

https://doi.org/10.2478/macvetrev-2018-0012 pressure, favourable climatic conditions, food availability, and other factors (3). This inevitably leads to increasing conflicts between humans and wild boars caused by serious economic losses due to crop damages (4), high environmental impact on animal and plant biodiversity (5), car accidents (6), and injuries (7) or even death (8) occurring as a result of attacks on humans. From an epidemiological point of view, wild boars can harbour and spread into the environment many biological agents that are transmissible to other wildlife, domestic animals, and humans (9). These animals are omnivorous, they have opportunistic feeding habits, and they eat different types of diets. Because of their feeding habits, wild boars play a significant role in the maintenance and circulation of some parasites, especially Toxoplasma and Trichinella.

Among wild animals whose meat is destined for human consumption, tissue cysts of $T$. gondii in meat of wild boars are a potential source of toxoplasmosis for humans (10). Serological 
evidence of Toxoplasma infection in wild boars has largely been reported worldwide (11), with $14 \%$ of seropositive wild boars found in Italy (12). Furthermore, a coprological survey on parasites affecting wild boars in this country showed a total prevalence of $78.86 \%$ (13). In the last years, consistent wild boar populations frequently enter urban areas or live and thrive in metropolitan areas of important cities, becoming synanthropic animals (14). Since humans may accidentally share the same outdoor areas with wild boars, a potential risk may exist for contacts between humans and environments contaminated by zoonotic parasites shed from wild boars $(15,16)$.

Therefore, studies on wild boar parasites are important to evaluate the extent to which these animals can represent a source of infections for humans. Examination of these parasitic diseases in terms of prevalence, strain or pathogenicity etc., might give further insight into zoonotic infections and may facilitate the implementation of control measures.

For these reasons, the aim of the present survey was to determine (i) the seroprevalence and genotypes of $T$. gondii and (ii) the occurrence of helminth infections potentially transmissible to humans in wild boars hunted in central Italy.

\section{MATERIAL AND METHODS}

\section{Sample collection and animals examined}

\subsection{Study area}

Two hundred and thirteen serum samples, 65 diaphragm samples, 50 faecal samples, and 32 small intestines were collected from 213 carcasses of wild boars killed by authorized hunters during the 2016-2017 hunting season (from November 2016 to January 2017) in the province of Pisa $\left(43^{\circ} 43^{\prime} \mathrm{N}\right.$ $10^{\circ} 24^{\prime} \mathrm{E}$ ), Tuscany, central Italy. Difference in the number of samples was caused by difference in hunters' willingness to cooperate. Many hunters did not allow the collection of all samples (blood, faeces, small intestine) from carcasses, because sampling was a cause of slow down of the evisceration steps.

\subsection{Wild boars}

After killing, hunted wild boars were transported to special facilities equipped for slaughtering, where carcasses were skinned and eviscerated, and meat was butchered for human consumption. Before skinning, the sex and age of wild boars were determined. The animals were classified as juveniles $(<18$ months of age) and adults $(\geq 18$ months of age) according to the tooth eruption pattern (17). Altogether, carcasses of 112 males, 101 females, 178 adults (91 females, 87 males), and 35 juveniles (25 males, 10 females) were sampled. All wild boars were in good body conditions with significant subcutaneous fat deposits.

\subsection{Sample collection}

Specimens were collected from the hunted animals during evisceration of the thoracic and peritoneal cavities. Blood samples $(n=213)$ were taken from the thoracic cavity using a $20 \mathrm{ml}$ syringe, transferred into $50 \mathrm{ml}$ falcon vials, and left to coagulate at room temperature. Approximately $25 \mathrm{~g}$ of muscle samples $(\mathrm{n}=65)$ were collected from the diaphragm of each animal and put in individual plastic bags. Fecal samples $(\mathrm{n}=50)$ were taken directly from the rectal ampulla and placed into plastic containers. Small intestines $(n=32)$ were individuated, isolated from the entire gastrointestinal tract by scissors, ligatured at both ends, and wrapped in plastic bags. Blood samples were centrifugated at $2000 \mathrm{~g}$ for $15 \mathrm{~min}$ to separate the sera.

\subsection{Labeling and storing}

After collection, all samples were labelled by sex and age of the animal, placed in insulated containers with refrigerant gel packs, and brought to laboratory. Upon arrival serum samples were transferred in $1.5 \mathrm{ml}$ eppendorf tubes, while coprological samples were stored at $+5^{\circ} \mathrm{C}$ until faecal examination was performed. Sera, diaphragm samples, and small intestines were frozen at $-20^{\circ} \mathrm{C}$ pending serological test, molecular analysis, and visual inspection, respectively. Frozen samples were then thawed at room temperature before their examination.

\section{Serological tests}

All sera were examined for anti-T. gondii $\operatorname{IgG}$ antibodies by the modified agglutination test (MAT). A commercial test kit (Toxo Screen DA ${ }^{2}$, bioMérieux, Lyon, France) containing formalintreated Toxoplasma tachyzoites as antigen was used according to the manufacturer's instructions. Positive and negative control sera were included into each test. Serum samples were diluted two-fold starting at a 1:10 dilution until reaching the endpoint titre. Sera with MAT titres of 1:10 or higher were considered positive (18). 


\section{Molecular and genotyping analysis}

Portions of diaphragm muscle were submitted to DNA extraction with Tissue Genomic DNA Extraction Kit (Fisher Molecular Biology, Trevose, PA, USA) following manufacturer's instructions. Extracted DNA was submitted to amplification by a nested-PCR (n-PCR) protocol, which amplifies a 193-bp fragment in the first round and a 96-bp fragment in the second round (19). Results were visualized using 2\% agarose gel electrophoresis stained with ethidium bromide. Genotyping of the DNA samples from wild boars testing positive in the n-PCR assay was performed by multi-locus PCR-restriction fragment length polymorphism (PCR-RFLP) using 12 genetic markers (20).

\section{Faecal examination}

Faecal samples (approximately 3 g) were examined by light microscopy for helminth eggs and protozoal oocysts by using a commercial sodium nitrate solution (Coprosol ${ }^{\circledR}$, Candioli Farmaceutici S.p.A., Beinasco (TO), Italy) with specific gravity 1,200. Helminth eggs and protozoal oocysts were identified according to their morphological features (21).

\section{Postmortem examination of the small intestine}

At necropsy, we focused on two selected zoonotic helminths that live in the intestine of wild boars, i.e. Ascaris suum and Macracanthorhynchus hirudinaceus. Their presence can be easily detected when the intestinal content is macroscopically evaluated by thorough examination, because both A. suum and $M$. hirudinaceus are large worms: adult parasites measure 15 to 40 and 5 to $47 \mathrm{~cm}$ in length, respectively (20). Therefore, the sieving technique was not used, although examination of the small intestines with the naked eye is not enough for detection of all parasite species. The small intestines originated from the same animals as the faecal samples. To detect $A$. suum and $M$. hirudinaceus infections, the small intestine was divided into 5 equally long sections, which were opened longitudinally in full length with a pair of surgical scissors and carefully examined by visual inspection of the intestinal content. When worms were detected, all visible worms were collected and rinsed briefly into lukewarm water, before fixation in $70 \%$ alcohol. The specimens of worms were identified by stereomicroscope examination based on morphological features of parasites (22).

\section{Statistical analysis}

Prevalence rates were calculated as number of positive animals/number of examined animals X 100 with the corresponding 95\% confidence intervals $(95 \% \mathrm{CI})$. Chi-square test was used to compare different prevalence values according to sex (females vs. males) and age (adults vs. juveniles)

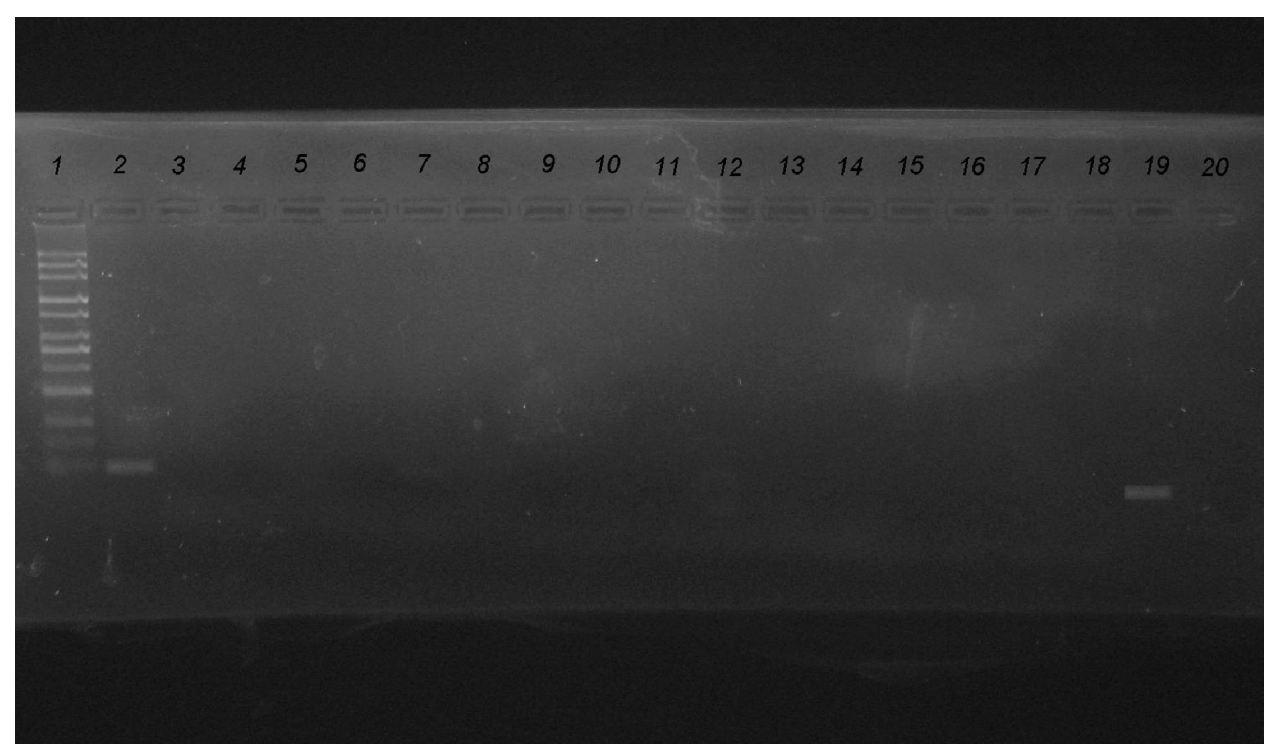

Figure 1. Electrophoresis of final nested-PCR products for Toxoplasma gondii DNA from diaphragms of wild boars. Lines 1: 100 bp DNA ladder. Line 2: positive control. Lines 3 to 18: negative samples. Line 19: positive sample. Line 20: negative control 
groups. P values $<0.05$ and $<0.01$ were considered significant and highly significant, respectively. Odd ratio (OR) and corresponding 95\% CI values were also calculated as a measure of the risk of infection. Total worm recovery (TWR), range $(\mathrm{R})$, mean intensity $(\mathrm{MI}) \pm$ standard error of the mean (SEM), and mean abundance (MA) \pm SEM were determined for $A$. suum and $M$. hirudinaceus harboured in the small intestine of wild boars.

\section{RESULTS}

\section{Serological results}

Anti-Toxoplasma antibodies were detected in sera from 26/213 (12.2\%, 95\% CI=7.8-16.6\%) wild boars, with MAT titres of 1:10 ( $n=11), 1: 20(n=9)$, $1: 40(n=4), 1: 80(n=1)$, and 1:160 $(n=1)$. Prevalence values were slightly higher in males $(12.5 \%$ [6.4$18.6 \%])$ than females $(11.9 \% \quad[5.6-18.2 \%])$ and remarkably higher in adult (14\% [8.9-19.1\%]) than juvenile $(2.8 \%$ [0-8.4\%]) wild boars, but statistical analysis showed no significant difference.

\section{Molecular and genotyping results}

Amplification of DNA by n-PCR assay was successful only in $1 / 65(1.5 \%$. 95\% CI=0-4.5\%) diaphragm sample and genetic characterization of DNA by PCR-RFLP technique revealed the occurrence of a genotype belonging to clonal type
II. The wild boar with n-PCR-positive muscle tissue was an adult female with a MAT titer of 1:40 (Fig. 1). The diaphragm was selected as a representative muscle in our study by convenience sampling. It is possible that Toxoplasma could be present in different muscles (heart, tongue, and others) of the examined wild boars.

\section{Coprological results}

According to faecal examination, the overall prevalence of helminth eggs and/or protozoa oocysts was $78 \%$. Metastrongylus spp was the most common parasite and was detected in $65 \%$ of wild boars, followed by Strongyles (22\%), A. suum (12\%), Coccidia (10\%), and Trichuris suis $(6 \%)$. Single infections were diagnosed in $52 \%$ of wild boars and mixed infections in $26 \%$. These results are presented in more detail in Table 1. A statistically significant difference was detected between coprological prevalence of endoparasite infections in males vs. females (chi-square $=4.675$, $\mathrm{P}=0.0306, \mathrm{OR}=4.45$ [1.08-18.29]).

\section{Intestinal examination}

Of the 32 small intestines examined, 3 (9.4\%, $95 \% \mathrm{CI}=0-19.5 \%$ ) from 2 juvenile males and 1 adult female harbored $M$. hirudinaceus while 2 (6.2\%, 0-14.6\%) from adult males harbored A. suum. Data on $\mathrm{TWR}, \mathrm{R}, \mathrm{MI} \pm \mathrm{SEM}$, and $\mathrm{MA} \pm \mathrm{SEM}$ are shown in Table 2.

Table 1. Distribution of endoparasites along with single and mixed infections in wild boars hunted in Tuscany (central Italy) according to sex and age groups, as determined by coprological analysis. Results are presented as number of positive animals with prevalence and $95 \%$ confidence interval in brackets

\begin{tabular}{|c|c|c|c|c|c|}
\hline Endoparasites & & Sex & & Age & Total $(n=50)$ \\
\hline & $\begin{array}{l}\text { Males } \\
(\mathrm{n}=32)\end{array}$ & $\begin{array}{c}\text { Females } \\
(n=18)\end{array}$ & $\begin{array}{c}\text { Juveniles } \\
(\mathrm{n}=17)\end{array}$ & $\begin{array}{l}\text { Adults } \\
(\mathrm{n}=33)\end{array}$ & \\
\hline Metastrongylus spp & $\begin{array}{c}18(56.2) \\
(39.1-73.4)\end{array}$ & $\begin{array}{c}10(55.6) \\
(32.6-78.5) \\
\end{array}$ & $\begin{array}{c}13(76.5) \\
(56.3-96.6) \\
\end{array}$ & $\begin{array}{c}15(45.4) \\
(28.5-62.4) \\
\end{array}$ & $\begin{array}{c}28(56) \\
(42.2-69.7) \\
\end{array}$ \\
\hline Strongyles & $\begin{array}{c}8(25) \\
(10-40)\end{array}$ & $\begin{array}{l}3(16.7) \\
(0-33.9)\end{array}$ & $\begin{array}{c}1(5.9) \\
(0-17.1)\end{array}$ & $\begin{array}{l}10(30.3) \\
(14.6-46)\end{array}$ & $\begin{array}{c}11(22) \\
(10.5-33.5)\end{array}$ \\
\hline Ascaris suum & $\begin{array}{c}6(18.7) \\
(5.2-32.3) \\
\end{array}$ & $\begin{array}{l}0(0) \\
(0-0) \\
\end{array}$ & $\begin{array}{l}2(11.8) \\
(0-27.1) \\
\end{array}$ & $\begin{array}{l}4(12.1) \\
(1-23.3) \\
\end{array}$ & $\begin{array}{l}6(12) \\
(3-21) \\
\end{array}$ \\
\hline Coccidia & $\begin{array}{c}3(9.4) \\
(0-19.5) \\
\end{array}$ & $\begin{array}{l}2(11.1) \\
(0-25.6) \\
\end{array}$ & $\begin{array}{c}1(5.9) \\
(0-17.1) \\
\end{array}$ & $\begin{array}{l}4(12.1) \\
(1-23.3) \\
\end{array}$ & $\begin{array}{c}5(10) \\
(1.7-18.3) \\
\end{array}$ \\
\hline Trichuris suis & $\begin{array}{c}3(9.4) \\
(0-19.5) \\
\end{array}$ & $\begin{array}{l}0(0) \\
(0-0)\end{array}$ & $\begin{array}{l}0(0) \\
(0-0)\end{array}$ & $\begin{array}{c}3(9.1) \\
(0-18.9) \\
\end{array}$ & $\begin{array}{c}3(6) \\
(0-12.6) \\
\end{array}$ \\
\hline Single infections & $\begin{array}{c}19(59.4) \\
(42.4-76.4) \\
\end{array}$ & $\begin{array}{c}7(38.9) \\
(16.4-61.4) \\
\end{array}$ & $\begin{array}{c}12(70.6) \\
(48.9-92.2) \\
\end{array}$ & $\begin{array}{c}14(42.4) \\
(25.6-59.3) \\
\end{array}$ & $\begin{array}{c}26(52) \\
(38.1-65.8) \\
\end{array}$ \\
\hline Double infections & $\begin{array}{c}8(25) \\
(10-40)\end{array}$ & $\begin{array}{l}4(22.2) \\
(3-41.4)\end{array}$ & $\begin{array}{c}1(5.9) \\
(0-17.1)\end{array}$ & $\begin{array}{c}11(33.3) \\
(17.2-49.4)\end{array}$ & $\begin{array}{c}12(24) \\
(12.2-35.8)\end{array}$ \\
\hline Triple infections & $\begin{array}{r}1(3.1) \\
(0-9.1) \\
\end{array}$ & $\begin{array}{l}0(0) \\
(0-0) \\
\end{array}$ & $\begin{array}{c}1(5.9) \\
(0-17.1) \\
\end{array}$ & $\begin{array}{l}0(0) \\
(0-0) \\
\end{array}$ & $\begin{array}{c}1(2) \\
(0-5.9) \\
\end{array}$ \\
\hline Total & $\begin{array}{l}28(87.5) \\
(76-99)^{*}\end{array}$ & $\begin{array}{c}11(61.1) \\
(38.6-83.6)^{*}\end{array}$ & $\begin{array}{c}14(82.3) \\
(64.2-100)\end{array}$ & $\begin{array}{c}25(75.8) \\
(61.1-90.4) \\
\end{array}$ & $\begin{array}{c}39(78) \\
(66.5-89.5) \\
\end{array}$ \\
\hline
\end{tabular}

*Statistically significant difference (chi-square $=4.675, \mathrm{P}=0.0306, \mathrm{OR}=4.45$ [1.08-18.29]) 
Table 2. Number of positive samples (Pos.), prevalence ( $\%$ ) and $95 \%$ confidence interval ( $95 \% \mathrm{CI})$, total worm recovery (TWR), range (R), mean intensity (MI) \pm standard error of the mean (SEM), and mean abundance (MA) \pm SEM of Macracanthorhynchus hirudinaceus and Ascasris suum in the small intestine of wild boars ( $\mathrm{n}=32$ ) hunted in Tuscany, central Italy

\begin{tabular}{lcccccc}
\hline Agent & Pos. & \% (95\% CI) & TWR & R & MI \pm SEM & MA \pm SEM \\
\hline M. hirudinaceus & 3 & $9.4 \%(0-19.5 \%)$ & 6 & $1-4$ & $2.0 \pm 1.0$ & $0.2 \pm 0.13$ \\
A. suum & 2 & $6.2 \%(0-14.6 \%)$ & 3 & $1-2$ & $1.5 \pm 0.5$ & $0.1 \pm 0.07$ \\
\hline
\end{tabular}

\section{DISCUSSION}

Game meat is traditionally consumed in the European Union (from 0.08 to $8.4 \mathrm{~kg}$ per capita per year) and in recent years, wild food has increased in popularity among new groups of people (23). Wild boars are popular and abundant game animals in many countries. Meat from hunted wild boars is highly appreciated by consumers because of its excellent organoleptic characteristics (24) and is always destined to human consumption, since hunters tend to eat what they kill and share it with relatives and friends, or it is sold to the local market for production of meat products. Hunting of wild boars is not only a popular recreational sport, but also a population control method supported by wildlife agencies because of the growth of wild boar populations (25). All these factors can contribute to increase the availability of wild boar meat for both home consumption and market. Our serological results show a level of exposure to $T$. gondii in wild boars hunted in central Italy. This suggests that the parasite is widespread in their habitat (frequently close to human settlements) and that $T$. gondii cysts are present in tissues of seropositive animals. The present seroprevalence $(12.2 \%)$ is close to that previously registered (14\%) in wild boars in Italy (12). However, it is much lower compared to most countries where a pooled worldwide seroprevalence of toxoplasmosis in wild boars has been estimated to be $23 \%$ (11). Different serologic assays and other factors can influence detection of antibodies, making it difficult to compare seroprevalence values among studies with differences in diagnostic methods, study areas, animal populations, and sampling procedures. Therefore, comparison of the present results with data reported in other countries is difficult and should be performed with caution. Eating undercooked or cured game is a widespread habit among game meat consumers. In particular, wild boar meat can be prepared for production of homemade sausages in Italy, where fresh sausages are frequently consumed raw or undercooked (e.g. grilled). Raw spleen and liver of a wild boar have been demonstrated to be the source of an outbreak of acute toxoplasmosis in humans (26). A case of acute toxoplasmosis in an adolescent girl, almost certainly related to the consumption of raw pork sausages, has been described (27). Like trichinellosis, game consumers may be at greatest risk of acquiring toxoplasmosis from consumption of undercooked wild boar meat (11). Moreover, hunters may also acquire toxoplasmosis from evisceration and handling of Toxoplasma infected wild boars, since seropositivity rate for antiToxoplasma antibodies in slaughterhouse workers was found to be remarkably high (72\%) in Brazil, suggesting a considerable risk associated with skinning of animals and handling raw meat (28).

The low prevalence rate $(1.5 \%)$ of $T$. gondii DNA in diaphragm could be due to the small size of the analyzed samples and/or to the low presence of tissue cysts in the muscle samples, thus portions of tissue harboring $T$. gondii cysts had no chance of being sampled. Previous surveys on the presence of $T$. gondii DNA in wild boars in the Western Alps (Norther Italy) and Spain showed much higher prevalence of $16.19 \%$ (29) and 15\% (30), respectively. The single genotyped strain in this survey belonged to type II lineage. To the best of our knowledge, this is the first study on $T$. gondii genotyping from wild boar samples in Italy. In this country, only type II strains have been identified in sheep (31) and have been associated with ovine abortion (32). Previous surveys on the genotypes of T. gondii in wild boars showed wide geographical variations. In France, all isolates $(n=21)$ were found to belong to the type II lineage (16). In Spain, wild boars $(n=9)$ were infected most frequently by type I and type II though mixed infections (types I + III) were also detected (30). In the Peninsular Malaysia, all the isolates $(n=6)$ were determined to be of clonal type I (33). In Iran, molecular evaluation confirmed the presence of type III and, to a more limited extent, of type I (34). Due to the low number and non-representative geographic distribution of samples analysed, we cannot exclude that other genotypes are also present in wild boars in Italy.

The coprological positivity rate $(78 \%)$ to helminth infections in our survey is very close to 
$78.86 \%$ found in a similar investigation previously performed in Italy (13), but lower than $98.4 \%$ detected in Poland (35). It is well known that host factors such as age and sex can influence the presence of helminths. In the current study, the coprological prevalence of helminth infections was statistically higher in males than in females (Table 1). It is likely that this is due to variation in behavior, as males have larger home range size than females and have been recorded traveling more than females (36). If parasitic contamination of the environment occurs, males with a wide home range could be more likely to be exposed to areas contaminated by parasite infective stages during their life. In $68 \%$ (55.1-80.9\%) and 15.6\% (3-28.2\%) of the analysed faecal samples and small intestines from wild boars, respectively, helminth infections potentially dangerous for humans were detected. Combining results of coprological analysis and examination of the small intestine, they included $A$. suum, M. hyrudinaceus, T. suis and Metastrongylus spp. These parasites occur worldwide and have previously been reported in wild boars $(13,35,37$, $38,39,40,41)$. Their eggs are excreted in stool of infected hosts, including domestic pigs, wild boars and other suids.

Small numbers of the roundworm A. suum ranging from one to two adults per wild boar were found in two of the 32 small intestines examined. This suggests that the majority of wild boars harboured no or few roundworms. Other authors have reported the number of Ascaris per infected animal and described MA of 0.05 to 0.1 in Corsica (37) and MI of 1.0 in Spain (38). This is in agreement with the low MA (0.1) and MI (1.5) found in the present study. Infection rates of $A$. suum previously described in wild boars by necropsy findings, range from $0 \%$ in a locality of Corsica (37) to $56 \%$ in Hyogo Prefecture in Japan (39). Using the standard flotation method, we identified Ascaris eggs in $12 \%$ of fecal samples from wild boars. This agrees with infection rates of ascaridosis reported in wild boars by coprological analysis, ranging between $0 \%$ in Italy (40) and 25\% in Spain (41). Ascaridosis is transmitted by the faecal-oral route. The most important factor determining the transmission of Ascaris infection in wild boars appears to be the contamination of soil with infective eggs. A. suum eggs remain capable of being infectious for a long time because they are very resistant to drying and are well adapted to a wide range of temperatures (42). Earthworms and dung beetles may ingest Ascaris eggs while feeding on soil and faeces. When that happens, eggs can hatch and infective larvae can remain in the tissues of earthworms and dung beetles until a definitive host eats them, giving rise to the possibility that these invertebrates may serve as paratenic hosts in the life cycle of A. suum (43, 44). It is possible, that under certain circumstances the opportunities for ingestion of infective Ascaris eggs is reduced. A. suum has been reported to be an important source of human ascariasis in Denmark (45), Japan (46), United Kingdom (47), China (48), and Europe (49). The larvae of $A$. suum can migrate into the tissues of many animals including man. Seropositivity for A. suum was detected in $13.2 \%$ and $33 \%$ of patients suspected of visceral and visceral/ocular larva migrans in Austria (50) and the Netherlands (51), respectively. Ascaris lumbricoides is the closely related species infecting humans. Because adult $A$. suum and A. lumbricoides worms are morphologically indistinguishable, it has been a matter of debate as to whether they represent the same or different species (52). A hybrid A. suum/A. lumbricoides infection has been described in a pig farmer in Italy (53). Evidence of natural cross-transmission between humans and pigs has been reported in Africa but its extent across the globe is unknown (49). Ascaris infections often are asymptomatic among humans, but symptoms can include gastrointestinal discomfort, cough, lung inflammation, intestinal obstruction, and growth delays (54).

As expected, all M. hirudinaceus infections were undetected by faecal flotation technique in sodium nitrate solution. Thus, the present study fully corroborates the findings of other authors (41). The acanthocephalan M. hirudinaceus, commonly known as the giant thorny headed worm, occurs not only in pigs, wild boars and other suids but also in dogs, red foxes, and jackals (55). M. hirudinaceus has been routinely found in studies on helminth fauna of wild boars. Reported prevalences range from $5.9 \%$ in Italy (40) to $64 \%$ in Iran (56) with TWC varying from one to 117 in single infected hosts and MI of $18 \pm 4$ in Iran again (57). In the present study, $9.4 \%$ of wild boars were infected and the number of adult worms recovered per wild boar varied from one to four (MI of 3.06), suggesting that wild boars could play a rather limited role in the epidemiology of $M$. hirudinaceus in the study area. Definitive hosts become infected through the ingestion of different species of dung beetles (Scarabaeidae) harboring cystacanth larvae. Thus, differences in prevalence of $M$. hirudinaceus could be explained by a variability in the presence and number of dung beetles, which constitute the intermediate hosts of this parasite. Most of the 
infections documented in humans and attributed to M. hirudinaceus are from Thailand $(58,59)$ and China (60). A history of either accidental or intentional ingestion of arthropods, especially dung beetles, is related to human infections. Acute abdominal colic, intestinal ulcers and perforation requiring surgical emergency have been reported in humans $(58,59,60)$.

T. suis from wild boars and pigs is identical to Trichuris trichiura from humans and non-human primates with respect to morphology, life cycle, and localization in the intestinal mucosa. Additionally, the successful experimental transmission of T. suis from pigs to humans has been reported (61). In the present study, only three adult males $(6 \%)$ were infected. This is consistent with coprological prevalence values previously reported in literature, ranging from $4.9 \%$ in Italy (13) to $33.9 \%$ in Spain (41). There is no report of natural human infection by this parasite, so far. However, its zoonotic potential has been assessed $(62,63)$ and $T$. suis ova therapy has been shown to induce improvement in patients with active ulcerative colitis (64), Chron's disease (65), and allergic rhinitis (66).

Metastrongylus spp. was the most prevalent $(56 \%)$ helminth infection in fecal samples. Prevalences of Metastrongylus spp. according to other coprological surveys in wild boars range between $6.95 \%$ in Italy (13) and $62 \%$ in Poland (35). Differences in prevalence values could be explained by variations in the presence and number of earthworms, which form part of the diet of wild boars and act as intermediate hosts for this genus of nematodes carrying the L3 infective larvae. Metastrongylus apri, Metastrongylus asymmetricus, Metastrongylus elongatus, Metastrongylus pudendotectus, and Metastrongylus salmi have been recovered from wild boars and usually present mixed infections $(39,57)$. These species are indistinguishable from each other by coprological analysis because the technique does not allow differentiation of their egg morphology, being of very similar dimensions and shape. Human infections with M. apri, $M$. elongatus, and M. salmi have occasionally been identified as reported by other authors $(62,67)$, probably caused by the accidental ingestion of contaminated earthworms along with soiled foodstuffs. Patients may develop severe pulmonary infection with bilateral pleural effusion, productive cough with bloody thick sputum, fatigue, chest pain, and progressive dyspnea (67).

\section{CONCLUSION}

The present epidemiological survey is a source of valuable data on the epidemiology of zoonotic parasites in wild boars. This study indicates that T. gondii cysts may be present in tissues of wild boars hunted in central Italy and consumption of undercooked or raw wild boar meat (i.e., in fresh sausages) may expose humans to risk of Toxoplasma infection. The study also highlights the importance of high standard of hygiene during the handling of wild boar carcasses and that wild boars are hosts of helminths of veterinary and medical importance transmissible to pigs and humans. The occurrence of potentially zoonotic helminthiases in wild boars suggests the need to continue in the surveillance of these helminth species due to the increased proximity of wild boars to humans. Wild boars can have potential implications on public health and transmit parasites directly to humans through soil contamination with infective eggs (A. suum, T. suis) or indirectly by infecting intermediate hosts ( $M$. hirudinaceus, Metastrongylus spp). Considering that pigs share all parasitic species found in wild boars, the potential exists for introduction of these parasites into herds of domestic pigs as a result of increasing overlap of the range of wild boars with organic pig farms in Italy.

\section{CONFLICT OF INTEREST STATEMENT}

The authors declared that they have no potential conflict of interest with respect to the authorship and/or publication of this article.

\section{ACKNOWLEDGEMENT}

The authors would like to thank all the wild boar hunting teams for their important contribution and the University of Pisa for providing financial support to carry out this survey.

\section{REFERENCES}

1. Behavior and Biology of Wild Pigs. [Internet]. Available on line at http://wildpiginfo.msstate.edu/ behavior-feral-pigs.html (last access on September 20, 2017)

2. Santilli, F., Varuzza, P. (2013). Factors affecting wild boar (Sus scrofa) abundance in southern Tuscany. HYSTRIX 24 (2):169-173. 
3. Massei, G., Kindberg, J., Licoppe, A., Gačić, D., Šprem, N., Kamler, J., et al. (2015). Wild boar populations up, numbers of hunters down? A review of trends and implications for Europe. Pest Manag Sci. 71 (4): 492-500.

https://doi.org/10.1002/ps.3965

PMid:25512181

4. Amici, A., Serrani, F., Rossi, C. M., Primi, R. (2012). Increase in crop damage caused by wild boar (Sus scrofa L.): the "refuge effect". Agron Sustain Dev. 32 (3): 683-692.

https://doi.org/10.1007/s13593-011-0057-6

5. Massei, G., Genov, P. V. (2004). The environmental impact of wild boar. Galemys 16 (1): 135-145.

6. Rodríguez-Morales, B., Díaz-Varela, E. R., MareyPérez, M. F. (2013). Spatiotemporal analysis of vehicle collisions involving wild boar and roe deer in NW Spain. Accid Anal Prev. 60, 121-123. https://doi.org/10.1016/j.aap.2013.07.032 PMid:24056283

7. Kose, O., Guler, F., Baz, A. B., Akalin, S., Turan, A. (2011). Management of a wild boar wound: a case report. Wilderness Environ Med. 22 (3): 242-245. https://doi.org/10.1016/j.wem.2011.06.005 PMid:21962050

8. Manipady, S., Menezes, R. G., Bastia, B. K. (2006). Death by attack from a wild boar. J Clin Forensic Med. 13 (2): 89-91.

https://doi.org/10.1016/j.jcfm.2005.08.007 PMid:16263321

9. Meng, X. J., Lindsay, D. S., Sriranganathan, N. (2009). Wild boars as sources for infectious diseases in livestock and humans. Philos Trans R Soc Lond B Biol Sci. 364 (1530): 2697-2707.

https://doi.org/10.1098/rstb.2009.0086 PMid:19687039 PMCid:PMC2865094

10. Tenter, A. M., Heckeroth, A.R., Weiss, L. M. (2000). Toxoplasma gondii: from animals to humans. Int $\mathbf{J}$ Parasitol. 30 (12-13): 1217-1258. https://doi.org/10.1016/S0020-7519(00)00124-7

11. Rostami, A., Riahi, S. M., Fakhri, Y., Saber, V., Hanifehpour, H., Valizadeh, S., Gholizadeh, M., Pouya, R. H., Gamble, H. R. (2017). The global seroprevalence of Toxoplasma gondii among wild boars: A systematic review and meta-analysis. Vet Parasitol. 244, 12-20.

https://doi.org/10.1016/j.vetpar.2017.07.013 PMid:28917302

12. Ranucci, D., Veronesi, F., Moretti, A., Branciari, R., Miraglia, D., Manfredi, M. T., Piergili Fioretti, D. (2013). Seroprevalence of Toxoplasma gondii in wild boars (Sus scrofa) from central Italy. Parasite 20, 48. https://doi.org/10.1051/parasite/2013048

PMid:24280567 PMCid:PMC3841837
13. Moretta I., Veronesi, F., Di Paola, R., Battistacci, L., Moretti, A. (2011). Indagine parassitologica in cinghiali (Sus scrofa) cacciati nella stagione venatoria 2009-2010 in Umbria (Italia centrale). Large Anim Rev. 17, 187-192.

14. Cahill, S., Llimona, F., Caba-eros, L., Calomardo, F. (2012). Characteristics of wild boar (Sus scrofa) habituation to urban areas in the Collserola Natural Park (Barcelona) and comparison with other locations. Anim Biodivers Conserv. 35 (2): 221-233.

15. Mizgajska-Wiktor, H., Jarosz, W. (2010). Potential risk of zoonotic infections in recreational areas visited by Sus scrofa and Vulpes vulpes. Case study - Wolin Island, Poland. Wiad Parazytol. 56 (3): 243-251. PMid:21174955

16. Bojar, H., Kłapeć, T. (2012). Contamination of soil with eggs of geohelminths in recreational areas in the Lublin region of Poland. Ann Agric Environ Med. 19 (2): 267-270. PMid:22742799

17. Matschke, G. H. (1967). Aging European wild hogs by dentition. J Wildl Manage. 31 (1): 109-113. https://doi.org/10.2307/3798365

18. Richomme, C., Aubert, D., Gilot-Fromont, E., Ajzenberg, D., Mercier, A., Ducrot, C., Ferté, H., Delorme, D., Villena, I. (2009). Genetic characterization of Toxoplasma gondii from wild boar (Sus scrofa) in France. Vet Parasitol. 164 (2-4): 296-300.

https://doi.org/10.1016/j.vetpar.2009.06.014 PMid:19592170

19. Jones, C. D., Okhravi, N., Adamson, P., Tasker, S., Lightman, S. (2000). Comparison of PCR detection methods for B1, P30, and 18S rDNA genes of T. gondii in aqueous humor. Invest Ophthalmol Vis Sci. 41 (3): 634-644.

PMid:10711675

20. Su, C., Shwab, E. K., Zhou, P., Zhu, X. Q., Dubey, J. P. (2010). Moving towards an integrated approach to molecular detection and identification of Toxoplasma gondii. Parasitology 137 (1): 1-11. https://doi.org/10.1017/S0031182009991065 PMid:19765337

21. Sloss, M. W., Kemp, R. L. (1978). Veterinary clinical parasitology. Fifth Edition. Iowa State University Press, Ames, Iowa.

22. Casarosa, L. (1986). Parassitologia degli animali domestici. Casa Editrice Ambrosiana, Milano. PMid:3802571 PMCid:PMC1542647

23. Schulp, C. J. E., Thuiller, W., Verburg, P. H. (2014). Wild food in Europe: A synthesis of knowledge and data of terrestrial wild food as an ecosystem service. Ecol Econon. 105, 292-305. https://doi.org/10.1016/j.ecolecon.2014.06.018 
24. Sales, J., Kotrba, R. (2013). Meat from wild boar (Sus scrofa L.): a review. Meat Sci 94(2): 187-201. https://doi.org/10.1016/j.meatsci.2013.01.012 PMid:23501250

25. West, B. C., Cooper, A. L., Armstrong, J. B. (2009). Managing wild pigs: A technical guide. HumanWildlife Interactions Monograph 1, 1-55.

26. Choi, W. Y., Nam, H. W., Kwak, N. H., Huh, W., Kim, Y. R., Kang, M. W., Cho, S. Y., Dubey, J. P. (1997). Foodborne outbreaks of human toxoplasmosis. J Infect Dis. 175 (5): 1280-1282. https://doi.org/10.1086/593702

PMid:9129105

27. Vitale, M., Tumino, G., Partanna, S., La Chiusa, S., Mancuso, G., Giglia, M. L., Presti, V. D. (2014). Impact of traditional practices on food safety: a case of acute toxoplasmosis related to the consumption of contaminated raw pork sausage in Italy. J Food Prot. 77 (4): 643-646.

https://doi.org/10.4315/0362-028X.JFP-13-285 PMid:24680078

28. Riemann, H. P., Brant, P. C., Behymer, D., E., Franti, C., E. (1975). Toxoplasma gondii and Coxiella burneti antibodies among Brazilian slaughterhouse employees. Am J Epidemiol. 102 (5): 386-393. https://doi.org/10.1093/oxfordjournals.aje.a112177 PMid:1200023

29. Ferroglio, E., Bosio, F., Trisciuoglio, A., Zanet, S. (2014). Toxoplasma gondii in sympatric wild herbivores and carnivores: epidemiology of infection in Western Alps. Parasit Vectors. 7, 196. https://doi.org/10.1186/1756-3305-7-196 PMid:24766665 PMCid:PMC4012061

30. Calero-Bernal, R., Saugar, J. M., Fronters, E., Pérez-Martín, J. E., Habela, M. A., Serrano, F. J., Reina, D., Fuentes, I. (2015). Prevalence and genotype identification of Toxoplasma gondii in wild animals form southwestern Spain. J Wildl Dis. 51 (1): 233-238.

https://doi.org/10.7589/2013-09-233

PMid:25375939

31. Vismarra, A., Barilli, E., Miceli, M., Mangia, C., Genchi, M., Brindani, F., Kramer, L., Bacci, C. (2017). Toxoplasma gondii in the Cornigliese sheep breed in Italy: Meat juice serology, in vitro isolation and genotyping. Vet Parasitol. 243, 125-129. https://doi.org/10.1016/j.vetpar.2017.06.013 PMid:28807281

32. Chessa, G., Chisu, V., Porcu, R., Masala, G. (2014). Molecular characterization of Toxoplasma gondii type II in sheep abortion in Sardinia, Italy. Parasite 21, 6. https://doi.org/10.1051/parasite/2014007 PMid:24534616 PMCid:PMC3927306
33. Puvanesuaran, V. R., Noordin, R., Balakrishnan, V. (2013). Genotyping of Toxoplasma gondii isolates from wild boars in Peninsular Malaysia. PLoS ONE 8 (4): e61730.

https://doi.org/10.1371/journal.pone.0061730

PMid:23613920 PMCid:PMC3629149

34. Sarkari, B., Yaghoobi, K., Mansouri, M., Asgari, Q., Abdolahi, S. (2017). Seroprevalence and genotyping of Toxoplasma gondii in wild boars (Sus scrofa) from Southwestern Iran. Jundishapur J Microbiol. 10 (1): e39516.

35. Popiolek, M., Knechi, D., Szczęsna-Staśkiewicz, J., Czerwińska-Rożalow, A. (2010). Helminths of the wild boar (Sus scrofa L.) in natural and breeding conditions. Bull Vet Inst Pulawy. 54, 161-166.

36. Shannon, L. K., Fischer, J. W., Monaghan, A. J., Beasley, J. C., Boughton, R., Campbell, T. A., et al. (2017). Quantifying drivers of wild pig movement across multiple spatial and temporal scales. Mov Ecol. 5, 14. https://doi.org/10.1186/s40462-017-0105-1 PMid:28630712 PMCid:PMC5471724

37. Foata, J., Culioli, J.-L., Marchand, B. (2005). Helminth fauna of wild boar in Corsica. Acta Parasitol. 50 (2): 168-170.

38. de-la Muela, N., Hernández-de-Luján, S., Ferre, I. (2001). Helminths of wild boar in Spain. J Wildl Dis. 37 (4): 840-843.

https://doi.org/10.7589/0090-3558-37.4.840 PMid:11763752

39. Sato, H., Suzuki, K., Yokoyama, M. (2008). Visceral helminths of wild boars (Sus scrofa leucomystax) in Japan, with special reference to a new species of the genus Morgascaridia Inglis, 1958 (Nematoda: Schneidernematidae). J Helminthol. 82 (2): 159-168. https://doi.org/10.1017/S0022149X08936191 PMid:18328113

40. Magi, M., Bertani, M., Dell'Omodarme, M., Prati, M.C. (2005). Necropsy and coprology in wild boar (Sus scrofa) in Livorno Mountain Park (Tuscany, central Italy). Parassitologia 46 (3): 311-313.

41. Gassó, D., Feliu, C., Ferrer, D., Mentaberre, G., CasasDíaz, E., Velarde, R., et al. (2015). Uses and limitations of faecal egg count for assessing worm burden in wild boars. Vet Parasitol. 209 (1-2): 133-137. https://doi.org/10.1016/j.vetpar.2015.02.006 PMid:25725547

42. Kim, M.-K., Pyo, K.-H., Hwang, Y.-S., Park, K. H., Hwang, I. G., Chai, J.-Y., Shin, E.-H. (2012). Effect of temperature on embryonation of Ascaris suum eggs in an environmental chamber. Korean J Parasitol. 50 (3): 239-242. https://doi.org/10.3347/kjp.2012.50.3.239 PMid:22949753 PMCid:PMC3428571 
43. Roepstorff, A., Grønvold, J., Larsen, M. N., Kraglund, H.-O., Fagerholm, H.-P. (2002). The earthworm Lumbricus terrestris as a possible paratenic or intermediate host of the pig parasite Ascaris suum. Comp Parasitol. 69 (2): 206-210. https://doi.org/10.1654/1525-2647(2002)069[0206: TELTAA]2.0.CO;2

44. Nichols, E., Gómez, A. (2014). Dung beetles and fecal helminth transmission: patterns, mechanisms and questions. Parasitology 141 (5): 614-623.

https://doi.org/10.1017/S0031182013002011 PMid:24476794

45. Nejsum, P., Parker, E. D. Jr., Frydenberg, J., Roepstorff, A., Boes, J., Haque, R., Astrup, I., Prag, J. (2005). Ascariasis is a zoonosis in Denmark. J Clin Microbiol. 43 (3): 1142-1148.

https://doi.org/10.1128/JCM.43.3.1142-1148.2005

PMid:15750075 PMCid:PMC1081283

46. Arizono, N., Yoshimura, Y., Tohzaka, N., Yamada, M., Tegoshi, T., Onishi, K., Uchikawa, R. (2010). Ascariasis in Japan: is pig-derived Ascaris infecting humans? Jpn J Infect Dis. 63 (6): 447-448. PMid:21099099

47. Bendall, R. P., Barlow, M., Betson, M., Stohard, J. R., Nejsum, P. (2011). Zoonotic ascariasis, United Kingdom. Emerg Infect Dis. 17 (10): 1964-1966. https://doi.org/10.3201/eid1710.101826 PMid:22000387 PMCid:PMC3310658

48. Zhou, C., Li, M., Yuan, K., Deng, S., Peng, W. (2012). Pig Ascaris: an important source of ascariasis in China. Infect Genet Evol. 12 (6): 1172-1177. https://doi.org/10.1016/j.meegid.2012.04.016 PMid:22561394

49. Betson, M., Nejsum, P., Bendall, R. P., Deb, R. M., Stohard, J. R. (2014). Molecular epidemiology of ascariasis: a global perspective on the transmission dynamics of Ascaris in people and pigs. J Infect Dis. 210 (6): 932-941.

https://doi.org/10.1093/infdis/jiu193

PMid:24688073 PMCid:PMC4136802

50. Schneider, R., Auer, H. (2016). Incidence of Ascaris suum-specific antibodies in Austrian patients with suspected larva migrans visceralis (VLM) syndrome. Parasitol Res. 115 (3): 1213-1219. https://doi.org/10.1007/s00436-015-4857-5 PMid:26637313

51. Pinelli, E., Herremans, T., Harms, M. G., Hoek, D., Kortbeek, L. M. (2011). Toxocara and Ascaris seropositivity among patients suspected of visceral and ocular larva migrans in the Netherlands: trends from 1998 to 2009. Eur J Clin Microbiol Infect Dis. 30 (7): 873-879.

https://doi.org/10.1007/s10096-011-1170-9 PMid:21365288
52. Leles, D., Gardner, G. L., Reinhard, K., I-iguez, A., Araujo, A. (2012). Are Ascaris lumbricoides and Ascaris suum a single species? Parasit Vectors 5, 42. https://doi.org/10.1186/1756-3305-5-42 PMid:22348306 PMCid:PMC3293767

53. Dutto, M., Petrosillo, N. (2013). Hybrid Ascaris suum/lumbricoides (Ascarididae) infestation in a pig farmer: a rare case of zoonotic ascariasis. Cent Eur J Public Health. 21 (4) :224-226.

PMid:24592729

54. Notes from the field: ascariasis associated with pig farming - Maine, 2010-2013. Available on line at http://www.cdc.gov/mmwr/preview/mmwrhtml/ mm6220a6.htm (last access on September 20, 2017).

55. Dalimi, A., Sattari, A., Motamedi, Gh. (2006). A study on intestinal helminths of dogs, foxes and jackals in the western part of Iran. Vet Parasitol. 142 (1-2): 129-133.

https://doi.org/10.1016/j.vetpar.2006.06.024

PMid:16899340

56. Mowlavi, G. R., Massoud, J., Mobedi, I., SolaymaniMohammadi. S., Gharagozlou, M. J., Mas-Coma, S. (2006). Very highly prevalent Macracanthorhynchus hirudinaceus infection of wild boar Sus scrofa in Khuzestan province, south-western Iran. Helminthologia 43 (2): 86-91. https://doi.org/10.2478/s11687-006-0017-x

57. Eslami, A., Farsad-Hamdi, S. (1992). Helminth parasites of wild boar, Sus scrofa, in Iran. J Wildl Dis. 28 (2): 316-318.

https://doi.org/10.7589/0090-3558-28.2.316 PMid:1602589

58. Pradatsundarasar, A., Pechranond, K. (1965). Human infection with the acanthocephalan Macracanthorhynchus hirudinaceus in Bangkog: report of a case. Am J Trop Med Hyg. 14 (5): 774776.

https://doi.org/10.4269/ajtmh.1965.14.774 PMid:5829134

59. Radomyos, P., Chobchuanchom, A., Tungtrongchitr, A. (1989). Intestinal perforation due to Macracanthorhynchus hirudinaceus infection in Thailand. Trop Med Parasit. 40 (4): 476-477. PMid:2623433

60. Leng, Y. J., Huang, W. D., Liang, P. N. (1983). Human infection with Macracanthorhynchus hirudinaceus Travassos, 1916 in Guangdong province, with notes on its prevalence in China. Ann Trop Med Parasitol. 77 (1): 107-109. https://doi.org/10.1080/00034983.1983.11811681 PMid:6882052 
61. Beer, R. J. (1976). The relationship between Trichuris trichiura (Linnaeus 1758) of man and Trichuris suis (Schrank 1788) of the pig. Res Vet Sci. 20 (1): 47-54. PMid:1257627

62. Solaymani - Mohammadi, S., Mobedi, I., Rezaian, M., Massoud, J., Mohebali, M., Hooshyar, H., Ashrafi, K., Rokni, M. B. (2003). Helminth parasites of the wild boar, Sus scrofa, in Luristan province, western Iran and their public health significance. J Helminthol. 77 (3): 263-267.

https://doi.org/10.1079/JOH2003168

PMid:12895286

63. Nejsum, P., Betson, M., Bendall, R. P., Thamsborg, S. M. (2012). Assessing the zoonotic potential of Ascaris suum and Trichuris suis: looking to the future from an analysis of the past. J Helminthol. 86 (2):148-155.

https://doi.org/10.1017/S0022149X12000193

PMid:22423595

64. Summers R.W., Elliott, D. E., Urban, J. F. Jr, Thompson, R. A., Weinstock, J. V. (2005). Trichuris suis therapy for active ulcerative colitis: a randomized controlled trial. Gastroenterology 128(4): 825-832.

https://doi.org/10.1053/j.gastro.2005.01.005

PMid:15825065
65. Summers, R. W., Elliott, D. E., Urban, J. F. Jr, Thompson, R., Weinstock, J. V. (2005). Trichuris suis therapy in Crohn's disease. Gut 54 (1): 87-90. https://doi.org/10.1136/gut.2004.041749 PMid:15591509 PMCid:PMC1774382

66. Bager, P., Arnved, J., Renborg, S., Wohlfhart, J., Poulsen, L. K., Westergaard, T., et al. (2010). Trichuris suis ova therapy for allergic rhinitis: a randomized, double-blind, placebo-controlled clinical trial. J Allergy Clin Immunol. 125 (1): 123130.

https://doi.org/10.1016/j.jaci.2009.08.006

PMid:19800680

67. Calvopina, M., Caballero,H., Morita, T.Korenaga, M. (2016). Case report: human pulmonary Infection by the zoonotic Metastrongylus salmi nematode. The First reported case in the Americas. Am J Trop Med Hyg. 95 (4): 871-873. https://doi.org/10.4269/ajtmh.16-0247 PMid:27382078 PMCid:PMC5062791 